\title{
EFEKTIVITAS PENERAPAN TERAPI PERMAINAN SOSIALISASI UNTUK MENURUNKAN PERILAKU IMPULSIF PADA ANAK DENGAN ATTENTION DEFICIT HYPERACTIVE DISORDER
} (ADHD)

\author{
Deyla Erinta dan Meita Santi Budiani \\ Program Studi Psikologi Universitas Negeri Surabaya \\ Email: ita_peha@yahoo.com
}

\begin{abstract}
The Effectiveness of Socialization Play Therapy to Reduce Impulsive Behavior in Children with Attention Deficit Hyperactive Disorder (ADHD). The purpose of this study was to examine the effectiveness of socialization play therapy to reducing impulsive behavior in children. The research subjects were kindergarten students in State Special School (Sekolah Luar Biasa Negeri/SLB N) Gedangan Sidoarjo. This study employed quasi experiment with time series design. Purposive sampling techniques was used to collect the subjects which has the attention deficit hyperactive disorder (ADHAD) characteristics. Data collected using rating scale of impulsive behavior children with ADHD and analysed using Wilcoxon signed rank test. The result showed that $P$-value $=0,043$ with $\alpha=0,05$. It can be concluded from the results that the application of socialization play therapy is effective to reduce impulsive behavior in children with ADHD in SLB N Gedangan Sidoarjo.
\end{abstract}

Keywords: Socialization play therapy, impulsive behavior, children with ADHD.

\begin{abstract}
Abstrak: Penelitian ini bertujuan untuk menguji seberapa efektif terapi permainan sosialisasi dalam menurunkan perilaku impulsif pada anak ADHD. Subjek penelitian adalah siswa TK di SLB N Gedangan, Sidoarjo. Penelitian ini menggunakan metode kuantitatif dengan desain quasi experiment dengan jenis time series design. Pengambilan subjek penelitian menggunakan teknik purposive sampling yakni subjek yang memiliki karakteristik penderita ADHD. Pengumpulan data menggunakan rating scale perilaku impulsif pada anak dengan ADHD dan dianalisis menggunakan Wilcoxon sign rank test. Hasil analisis data diperoleh nilai $P$ - value atau sig sebesar 0,043 dengan taraf $\alpha=0,05$. Dengan demikian, dapat disimpulkan bahwa penerapan terapi permainan sosialisasi efektif untuk menurunkan perilaku impulsif pada anak ADHD di SLB N Gedangan, Sidoarjo.
\end{abstract}

Kata kunci: Terapi permainan sosialisasi, perilaku impulsif, anak dengan ADHD.

Anak berkebutuhan khusus, yang selanjutnya disebut sebagai ABK, merupakan anak dengan karakteristik khusus yang berbeda dengan anak pada umumnya. Karena karakteristik dan hambatan yang dimiliki, ABK memerlukan bentuk pelayanan pendidikan khusus yang disesuaikan dengan kemampuan dan potensi mereka (Somantri, 2006). Secara umum, berbagai bentuk gangguan ABK dapat digolongkan dalam tunanetra, tunarungu, tunagrahita, tunadaksa, tunalaras, kesulitan belajar, gangguan perilaku, anak berbakat, dan anak dengan gangguan kesehatan.

Attention deficit hyperactive disorder (ADHD) merupakan salah satu jenis kondisi berkebutuhan khusus yang termasuk dalam gangguan perilaku. ADHD adalah gangguan perkembangan dalam peningkatan aktivitas motorik anak-anak hingga menyebabkan aktivitas anak-anak yang cenderung berlebihan (Baihaqi dan Sugiarmin, 2006). 
ADHD ditandai oleh aktivitas motorik berlebih dan ketidakmampuan untuk memfokuskan perhatian (Nevid, 2005). Anakanak dengan gangguan demikian harus segera diberi penanganan yang tepat agar gangguannya tidak berlanjut ke usia remaja bahkan dewasa.

Perbedaan anak attention deficit hyperactive disorder (ADHD) dengan anak normal adalah dalam hal berinteraksi dengan orang lain. Anak ADHD memiliki perilaku impulsif, yaitu tindakan yang memiliki dorongan untuk mengatakan atau melakukan sesuatu yang tidak terkendali. Karena perilaku seperti ini, umumnya mereka dijauhi oleh teman-temannya. Anak ADHD memiliki cara berkomunikasi yang buruk, perilakunya sangat aktif seperti tidak bisa duduk diam sejenak di kursi, cara belajar sangat lamban terutama untuk latihan-latihan yang berkaitan dengan aktivitas sehari-hari, ketidakmampuan dalam mengontrol perilaku, dan cenderung lebih beresiko mengalami gangguan mood, kecemasan, dan masalah dalam hubungan dengan teman sebayanya (dalam Nevid, 2005).

Perilaku impulsif inilah yang sering menjadi problem ketika anak penderita ADHD masuk dalam lingkungan sekolah umum. Mereka akan selalu menjadi sumber kekacauan di kelas. Bahkan Zentall (dalam Puspandita, 2010) menyebutkan bahwa perilaku ini sering kali menjadi sumber konflik antara anak dengan teman, guru, bahkan dengan administrator sekolah. Berkaitan dengan masalah ini, konselor dapat mengambil peran untuk mengarahkan perilaku anak agar dapat belajar menyesuaikan diri dengan lingkungan sehingga mereka dapat menerima tugas dan berbagai aturan sekolah lainnya.

Berdasarkan beberapa hasil riset di Amerika yang dilakukan oleh Barkley dkk. (1993), terdapat 56\% anak ADHD memerlukan pembelajaran privat, $30 \%$ selalu mengulang kelas, dan $30 \%-40 \%$ ditempatkan di sekolah khusus. Selain itu, sekitar $46 \%$ anak ADHD diasingkan dari sekolah dan lebih dari $30 \%$ putus sekolah dan tidak menyelesaikan sekolah menengah atas. Anak dengan ADHD akan sulit untuk mengembangkan kemampuan emosionalnya dan selamanya mereka akan selalu menghadapi persoalan dalam mengatasi kemarahan, agresi, tekanan, dan ketertarikan. Keadaan ini akan membuat anak penderita ADHD selalu berada di posisi oposisional yang selalu menentang dan mengacaukan suasana serta menjadi sumber konflik yang menyusahkan (dalam Nevid, 2005).

Penyebab terjadinya ADHD terletak pada faktor gen yang merupakan faktor primer. Hal itu dapat dilihat dari kondisi sebagian besar anggota keluarga anak tersebut yang pada umumnya memiliki anak yang hiperaktif. Sedangkan faktor psikologis, sosial, dan biologis dapat menjadi faktor sekunder. ADHD melibatkan pola genetis yang sudah terberi, yaitu kurang aktifnya otak bagian depan dari korteks otak besar, bagian otak yang bertanggung jawab untuk menghambat impuls-impuls dan mempertahankan self-control (Barkley, 1997).

ADHD menimbulkan dampak yang buruk terhadap perkembangan kognitif, emosi, dan penyesuaian diri sosial anak, sehingga menimbulkan beban psikososial yang berat di rumah, sekolah, dan keluarga (Biederman dalam Nevid, 2005). Dampak lainnya dapat berupa prestasi akademik yang rendah, kesulitan dalam makan, tidur, dan menjaga kesehatan dirinya sendiri. Menurut penelitian selama ini, penyandang ADHD merupakan suatu gangguan yang bisa mengganggu kemampuan anak dalam melakukan aktivitas yang berkaitan dengan konsentrasi dan perilaku mereka. Menurut Barkley, ADHD merupakan gangguan perilaku yang timbul pada anak dengan pola 
gejala: tidak bisa diam dan gelisah sejenak di tempat duduknya (hiperaktif), tidak dapat memusatkan perhatian yakni kurangnya konsentrasi terhadap suatu hal, dan perilaku impulsif yakni perilakunya yang mengikuti kata hatinya sehingga membuatnya bertindak semaunya sendiri tanpa dipikirkan terlebih dahulu (dalam Nevid, 2005).

Beberapa upaya telah dilakukan oleh para terapis, psikolog, termasuk oleh orang tua untuk mengatasi atau meminimalisir gangguan-gangguan perkembangan yang dialami oleh anak ADHD. Beberapa upaya yang sering dilakukan adalah farmakoterapi, terapi perilaku, terapi nutrisi, terapi musik, terapi lumba-lumba, dan terapi bermain. Namun penggunaan terapi yang paling digemari dan dipilih oleh orang tua dan anak adalah terapi bermain. Karena pada dasarnya seorang anak membutuhkan bimbingan pada perilakunya, maka dibutuhkan suatu permainan yang berfokus pada kegiatan gerak motorik tubuhnya. Menurut Freud dan Erikson (dalam Santrock, 1995), permainan adalah suatu bentuk penyesuaian diri manusia yang sangat berguna, menolong anak menguasai kecemasan dan konflik. Permainan memungkinkan anak melepaskan energi fisik yang berlebihan dan membebaskan perasaan-perasaan yang terpendam. Menurut Jeffree (dalam Dolphio, 2009), permainan-permainan dapat bersifat terapeutik sehingga dapat digunakan sebagai salah satu alternatif untuk menyembuhkan perilaku maladaptif bagi anak ADHD. Selain itu, terapi bermain juga diyakini dapat menyelesaikan kesulitan-kesulitan psikososial dan mendorong anak untuk mencapai pertumbuhan dan perkembangan yang optimal (Veskarisyanti, 2008).

Jeffree (dalam Dolphio, 2009) menyatakan bahwa perilaku impulsif yang dimiliki anak ADHD sangat mengganggu dan bisa menyebabkan dia dijauhi orang lain. Karena itu mereka memerlukan terapi bermain yang menekankan pada sosialisasi atau interaksi dengan teman-temannya. Jenis terapi permainan sosialisasi merupakan suatu upaya yang dapat menghantarkan anak yang bersangkutan melalui permainan tertentu agar mampu menguasai keterampilanketerampilan baru yang kemudian dikembangkan menjadi keterampilan khusus. Dalam terapi permainan sosialisasi, anak akan diajak untuk berinteraksi dengan teman sepermainan dan juga dengan terapisnya. Anak akan diajak untuk menyelesaikan tugas hingga selesai, tidak mengambil sesuatu yang bukan miliknya, dan juga diajarkan untuk bisa sabar dalam menunggu antrian atau giliran dalam suatu kegiatan.

Menurut Jeffree (dalam Dolphio, 2009), terdapat 5 jenis permainan sosialisasi yaitu meluncur di tempat peluncuran, bermain ayunan, melempar bola, bermain puzzle atau mainan bongkar pasang, dan estafet bola. Kelima jenis permainan tersebut dapat membantu menurunkan perilaku impulsif anak ADHD. Terapi permainan sosialisasi memiliki tahapan-tahapan yang akan dilewati selama terapi tersebut berlangsung, yaitu tahap awal, tahap pengenalan tugas, tahap pengalihan sasaran, tahap kerja sama, tahap relaksasi, hingga sampai pada tahap evaluasi. Terapi permainan sosialisasi ini juga memiliki kelebihan yang tidak diperoleh dari terapi yang lain, yaitu anak akan cenderung merasa nyaman saat berlangsungnya sesi terapi. Kelebihan lainnya, terapi bermain juga merupakan salah satu penanganan yang bisa dilakukan baik di rumah, di sekolah, maupun di tempat terapi.

Namun, banyak guru atau terapis yang menangani anak ADHD lebih fokus pada perilaku hiperaktif mereka dan kurang menyentuh perilaku impulsifnya. Seringkali hal ini disebabkan oleh kesalahpahaman bahwa anak dengan ADHD adalah anak yang hiperaktif. Padahal hiperaktivitas hanyalah salah satu ciri dari ADHD. Karakteristik 
ADHD lainnya yang sama penting adalah impulsivitas. Hal inilah yang menjadi salah satu alasan dilakukannya penelitian ini. Perilaku impulsif tidak dapat dibiarkan begitu saja tanpa adanya penanganan dan perhatian khusus dari orang sekitar.

Berdasarkan uraian latar belakang di atas, penelitian ini bertujuan untuk menguji seberapa efektif terapi permainan sosialisasi dalam menurunkan perilaku impulsif pada anak ADHD. Rumusan masalah penelitian ini diformulasikan sebagai berikut: "Apakah penerapan terapi permainan sosialisasi secara efektif dapat menurunkan perilaku impulsif pada anak ADHD?" Hipotesis dalam penelitian ini adalah terapi permainan sosialisasi efektif untuk menurunkan perilaku impulsif pada anak dengan ADHD.

\section{METODE}

Penelitian ini menggunakan metode quasi-experimental dengan jenis time series design. Desain penelitian ini hanya menggunakan satu kelompok saja sehingga tidak memerlukan kelompok kontrol. Sebelum diberi perlakuan terapi permainan sosialisasi, kelompok diberi pre-test sampai empat kali, dengan maksud untuk mengetahui kestabilan dan kejelasan keadaan kelompok sebelum diberi perlakuan. Setelah perlakuan, mereka diberi post-test dengan menggunakan instrumen yang sama dengan yang digunakan dalam pre-test. Perbedaan skor antara pre-test dan post-test merupakan efek atau pengaruh dari perlakuan. Alasan penggunaan metode desain time series adalah karena subjek merupakan kelompok anak yang mengalami ADHD. Mereka memiliki kekhususan atau pengecualian (dalam menerima instruksi atau arahan dalam beberapa hal, baik dalam belajar, bermain, maupun aktivitas lain yang mereka lakukan) dibandingkan anak normal. Penelitian yang digunakan pada anak ADHD dilakukan melalui observasi pre-test dan post- test secara berkelanjutan dalam waktu tertentu yang menunjukkan bahwa ada perubahan perilaku impulsif pada anak ADHD itu atau tidak. Penelitian ini memiliki beberapa variabel yang akan diteliti, yaitu terapi permainan sosialisasi sebagai variabel independen atau bebas (X) dan perilaku impulsif sebagai variabel dependen atau terikat(Y).

\section{Partisipan}

Penelitian ini menggunakan populasi TK kelas C anak ADHD di Sekolah Luar Biasa Negeri (SLBN) Gedangan, Sidoarjo. Teknik pengambilan sampel yang digunakan dalam penelitian ini adalah purposive sampling, yaitu teknik sampling yang digunakan oleh peneliti berdasarkan kriteria tertentu dalam pengambilan sampelnya (Arikunto, 2009). Penelitian ini mengambil siswa sebanyak 5 anak yang memiliki karakteristik sebagai berikut: siswa dengan jenis kelamin laki-laki dan perempuan dan mengalami ADHD dengan tipe impulsif.

Kelima anak tersebut merupakan jumlah keseluruhan dari siswa TK kelas C, dimana kelima-limanya memiliki karakteristik yang disebutkan di atas. Sementara itu, pada kelas A dan B merupakan gabungan dari beberapa anak berkebutuhan khusus yang memiliki gangguan yang bukan ADHD. Mengingat jumlah populasi sangat kecil dan sudah memiliki karakteristik yang sama dan sesuai dengan apa yang dikehendaki dalam penelitian ini, maka seluruh siswa tersebut dijadikan subjek penelitian.

\section{Prosedur}

Adapun prosedur dalam pelaksanaan penelitian ini adalah sebagai berkut: pertama, dalam penerapan terapi permainan sosialisasi untuk membantu pelaksanaan penelitian ini dilakukan koordinasi dengan terapis yang ahli 
dan berpengalaman yang berasal dari salah satu tempat terapi di Sidoarjo.

Kedua, memberikan pre-test selama empat kali untuk mengetahui seberapa konsisten perilaku impulsif pada subjek dengan menggunakan rating scale untuk mengukur perilaku impulsif seperti keengganan menunda respon, bertindak tanpa dipikirkan dahulu, dan reaktif.

Ketiga, memberikan perlakuan kepada subjek yang diketahui memiliki perilaku impulsif. Perlakuan yang diberikan berupa terapi permainan sosialisasi yang terdiri dari meluncur di tempat peluncuran, bermain ayunan, melempar bola, bermain puzzle atau bongkar pasang, dan estafet bola. Terapi permainan sosialisasi akan diberikan sebanyak 5 kali treatment dalam satu minggu karena semakin banyak treatment yang diberikan maka akan semakin jelas tingkat perbedaan antara sebelum dan setelah diberikan perlakuan.

Keempat, memberikan post-test untuk mengetahui perubahan perilaku setelah diberi perlakuan dengan terapi permainan sosialisasi dengan pengamatan yang intensif terhadap $\mathrm{s}$ e $\mathrm{t}$ i a $\mathrm{p}$ perubahan perilaku pada $\mathrm{s}$ u b j e k sebanyak 2 kali. Setelah itu dilakukan pembandingan pre-test dan post-test untuk menentukan seberapa besar perbedaan yang timbul. Selanjutnya dilakukan analisis statistik yang tepat untuk menentukan efektivitas penerapan terapi permainan sosialisasi untuk menurunkan perilaku impulsif pada anak dengan ADHD.

\section{Teknik Pengumpulan Data}

Pengumpulan data dalam penelitian ini menggunakan metode observasi untuk mengukur perilaku impulsif dan mengetahui efektivitas terapi permainan sosialisasi. Penelitian ini menggunakan rating scale dan check list sebagai alat ukur. Perilaku impulsif anak diukur dengan pedoman observasi jenis rating scale (pencatatan gejala menurut tingkatannya) yang disusun berdasarkan skala Likert dengan dua kriteria penilaian, yaitu muncul atau tidak muncul. Rating scale ini terdiri dari indikator-indikator perilaku impulsif anak ADHD dengan skor angka positif dan negatif. Jika anak berperilaku impulsif lebih banyak maka akan menghasilkan angka negatif, sedangkan anak yang berperilaku kurang atau tidak ada perilaku impulsif akan menghasilkan angka positif.

Tabel 1. Kriteria Penilaian Rating Scale Perilaku Impulsif

\begin{tabular}{ccl}
\hline Nilai & Kriteria Intensitas & \multicolumn{1}{c}{ Keterangan } \\
\hline $\mathbf{1}$ & Tidak pernah & Perilaku impulsif tidak muncul sama sekali \\
$\mathbf{2}$ & Jarang & Perilaku impulsif muncul selama 1-4 kali \\
$\mathbf{3}$ & Sering & Perilaku impulsif muncul selama 5-8 kali \\
$\mathbf{4}$ & Selalu & Perilaku impulsif muncul selama 9 atau lebih dari 9 kali \\
\hline
\end{tabular}

Kisi-kisi dalam pembuatan alat ukur berupa rating scale perilaku impulsif adalah sebagai berikut:

Tabel 1. 2. Kisi-Kisi Rating Scale Perilaku Impulsif

\begin{tabular}{|c|c|c|c|}
\hline Variabel & Aspek & Indikator & Aitem \\
\hline $\begin{array}{l}\text { Perilaku } \\
\text { Impulsif }\end{array}$ & $\begin{array}{l}\text { Keengganan } \\
\text { menunda respon } \\
\text { (ketidaksabaran) }\end{array}$ & $\begin{array}{l}\text { Menginterupsi } \\
\text { orang lain }\end{array}$ & $\begin{array}{l}\text { a. Menyelah percakapan } \\
\text { b. Menjawab pertanyaan yang tidak } \\
\text { ditujukan kepada dirinya } \\
\text { c. Melontarkan jawaban secara } \\
\text { terburu-buru terhadap pertanyaan } \\
\text { yang belum selesai ditanyakan }\end{array}$ \\
\hline
\end{tabular}




\begin{tabular}{|c|c|c|c|}
\hline Variabel & Aspek & Indikator & Aitem \\
\hline \multirow{4}{*}{$\begin{array}{l}\text { Perilaku } \\
\text { Impulsif }\end{array}$} & \multirow{3}{*}{$\begin{array}{l}\text { Bertindak tanpa } \\
\text { dipikirkan dahulu }\end{array}$} & $\begin{array}{l}\text { Memaksakan } \\
\text { kehendak pada } \\
\text { orang lain }\end{array}$ & $\begin{array}{l}\text { a. Merebut puzzle dengan paksa } \\
\text { b. Merebut bola dengan paksa } \\
\text { c. Mendorong teman tanpa sebab } \\
\text { saat bermain }\end{array}$ \\
\hline & & $\begin{array}{l}\text { Kesulitan } \\
\text { mengikuti aturan } \\
\text { dan perintah }\end{array}$ & $\begin{array}{l}\text { a. Mengikuti perintah terapis atau } \\
\text { guru sejak awal-akhir permainan } \\
\text { b. Memahami aturan atau perintah } \\
\text { dari terapis atau guru }\end{array}$ \\
\hline & & $\begin{array}{l}\text { Mengganggu } \\
\text { orang lain atau } \\
\text { usil di dalam } \\
\text { kelas atau saat } \\
\text { bermain }\end{array}$ & $\begin{array}{l}\text { a. Menyembunyikan alat tulis teman } \\
\text { b. Menyembunyikan puzzle teman } \\
\text { c. Mencubit teman } \\
\text { d. Menggoda teman } \\
\text { e. Menggoda guru atau terapis }\end{array}$ \\
\hline & Reaktif & $\begin{array}{l}\text { Sifat cenderung } \\
\text { tanggap atau } \\
\text { segera bereaksi } \\
\text { terhadap sesuatu } \\
\text { yang timbul atau } \\
\text { muncul }\end{array}$ & $\begin{array}{l}\text { a. Berteriak tanpa sebab yang jelas } \\
\text { b. Merespon panggilan (dari terapis } \\
\text { atau guru) yang tidak ditujukan } \\
\text { padanya } \\
\text { c. Membalas pukulan teman }\end{array}$ \\
\hline
\end{tabular}

Setelah dibuat kisi-kisi perilaku kisi check list kemampuan sosialisasi dengan impulsif, maka selanjutnya akan dibuat kisi- kriteria:

Tabel 2. Kriteria Check List Kemampuan Sosialisasi

\begin{tabular}{cc}
\hline Kriteria Penilaian & Keterangan \\
\hline Ya & Dapat melakukan \\
Tidak & Tidak dapat melakukan \\
\hline
\end{tabular}

Kemudian kisi-kisi kemampuan pedoman observasi saat penelitian adalah sosialisasi yang akan digunakan sebagai sebagaiberikut:

Tabel 2.1. Check List Kemampuan Sosialisasi

\begin{tabular}{|c|c|c|c|}
\hline Variabel & Aspek & Indikator & Aitem \\
\hline \multirow[t]{4}{*}{$\begin{array}{l}\text { Terapi } \\
\text { Permainan } \\
\text { Sosialisasi }\end{array}$} & $\begin{array}{l}\text { Kemampuan } \\
\text { mengikuti } \\
\text { tugas }\end{array}$ & $\begin{array}{l}\text { Saat Meluncur di } \\
\text { peluncuran }\end{array}$ & $\begin{array}{ll}\text { a. } & \text { Berdiri } \\
\text { b. } & \text { Berbaris } \\
\text { c. } & \text { Naik tangga } \\
\text { d. } & \text { Meluncur }\end{array}$ \\
\hline & & $\begin{array}{l}\text { Saat bermain } \\
\text { ayunan }\end{array}$ & $\begin{array}{ll}\text { a. Berdiri } \\
\text { b. Berbaris } \\
\text { c. Duduk di ayunan } \\
\text { d. Berayun } \\
\text { e. Mengayunkan teman }\end{array}$ \\
\hline & & $\begin{array}{l}\text { Saat bermain } \\
\text { melempar bola }\end{array}$ & $\begin{array}{ll}\text { a. } & \text { Berdiri } \\
\text { b. Berbaris } \\
\text { c. Ambil bola } \\
\text { d. Pegang bola } \\
\text { e. Lempar bola ke teman }\end{array}$ \\
\hline & & $\begin{array}{l}\text { Saat bermain } \\
\text { puzzle }\end{array}$ & $\begin{array}{ll}\text { a. } & \text { Berdiri } \\
\text { b. } & \text { Duduk melingkar } \\
\text { c. Mengambil puzzle } \\
\text { d. }\end{array}$ \\
\hline
\end{tabular}


Tabel 2.1. Check List Kemampuan Sosialisasi (lanjutan)

\begin{tabular}{|c|c|c|c|}
\hline Variabel & Aspek & Indikator & Aitem \\
\hline \multirow{3}{*}{$\begin{array}{l}\text { Terapi } \\
\text { Permainan } \\
\text { Sosialisasi }\end{array}$} & $\begin{array}{l}\text { Kemampuan } \\
\text { sosial }\end{array}$ & $\begin{array}{l}\text { Pada setiap } \\
\text { permainan }\end{array}$ & $\begin{array}{l}\text { a. Kontak mata } \\
\text { b. Mengajak teman bermain }\end{array}$ \\
\hline & $\begin{array}{l}\text { Kemampuan } \\
\text { berkomunikasi }\end{array}$ & $\begin{array}{l}\text { Pada setiap } \\
\text { permainan }\end{array}$ & $\begin{array}{l}\text { a. Bertanya pada terapis } \\
\text { b. Berbicara dengan teman } \\
\text { c. Menjawab pertanyaan terapis }\end{array}$ \\
\hline & $\begin{array}{l}\text { Kemampuan } \\
\text { bekerja sama }\end{array}$ & $\begin{array}{l}\text { Pada setiap } \\
\text { permainan }\end{array}$ & $\begin{array}{l}\text { a. Mengikuti jalannya permainan } \\
\text { b. Mengikuti aturan permainan } \\
\text { c. Mematuhi perintah terapis } \\
\text { d. Dapat bergiliran dalam bermain }\end{array}$ \\
\hline
\end{tabular}

\section{Teknik Analasis Data}

Data yang terkumpul berupa nilai skor hasil Check List atau Rating Scale perilaku impulsif aktivitas selama dan setelah terapi permainan sosialisasi selesai. Data ini dianalisis menggunakan Uji Jenjang Bertanda Wilcoxon pada SPSS 17.0. Uji Jenjang Bertanda Wilcoxon digunakan untuk membandingkan dua sampel yang tidak berpasangan atau independen, dimana populasinya berbeda dan jumlah sampel tidak sama. Uji ini bertujuan untuk mengetahui arah dan besarnya perbedaan dari sampel yang diambil. Uji Jenjang Bertanda Wilcoxon ini didasarkan atas tanda positif dan negatif dan juga atas besarnya perbedaan nilai pretest dan post-test. Efek $\mathrm{d}$ a r i variabe 1 eksperimen tidak dapat diukur melainkan hanya dapat diberi tanda positif dan negatif saja (Djarwanto, 2009). Dalam pengujian hipotesis pada penelitian ini, kriteria untuk menolak atau menerima $\mathrm{H}_{0}$ berdasarkan nilai significance (sig) dengan nilai $\alpha$ bernilai 0.05 .

\section{HASIL PENELITIAN}

Penelitian ini bertujuan untuk menguji seberapa efektif terapi permainan sosialisasi dalam menurunkan perilaku impulsif pada anak ADHD di SLBN Gedangan, Sidoarjo. Penelitian ini melibatkan 5 siswa sebagai subjek penelitian. Deskripsi data penelitian tersebut menunjukkan bahwa rata-rata hasil pre-test tersebut adalah 78 . Nilai tertinggi dalam pre-test tersebut adalah sebesar 82 dan terendah 72 . Sedangkan rata-rata hasil posttest adalah $59.4 \approx 59$ dengan nilai tertinggi dalam post-test adalah 61 dan terendah 58 .

Tabel 3. Deskripsi Data Statistik

\begin{tabular}{llllll}
\hline & $\mathrm{N}$ & Minimum & Maximum & Mean & Std. Deviation \\
\hline Pre-Tes & 5 & 72.00 & 82.00 & 77.6000 & 4.03733 \\
Pos-Tes & 5 & 58.00 & 61.00 & 59.4000 & 1.51658 \\
Valid N & 5 & & & & \\
(listwise) & & & & & \\
\hline
\end{tabular}

Bedasarkan hasil perhitungan analisis Wilcoxon dengan menggunakan bantuan program komputer SPSS versi 17.0 for windows diperoleh informasi tentang nilai signifikansi sebagaimana terdapat pada tabel 4.11 berikut ini: 
Tabel 4. Hasil Analisis Uji Tanda Wilcoxon

\begin{tabular}{llccc}
\hline \multicolumn{4}{c}{ Ranks } \\
\hline & $\mathrm{N}$ & Mean Rank & Sum of Ranks \\
\hline Post-tes - & Negative Rank: & $5 \mathrm{a}$ & 3.00 & 15.00 \\
Pre-tes & Positive Ranks & 0b & .00 & .00 \\
& Ties & 0c & & \\
& Total & 5 & & \\
\hline
\end{tabular}

a. postes < pretes

Test Statistics

\begin{tabular}{cc}
\hline & postes - pretes \\
\hline$Z$ & $-2.023 a$ \\
Asymp. Sig. & .043 \\
(2-tailed) & \\
\hline
\end{tabular}

pertama adalah Heni sebesar $24,17 \%$, Lus i sebesar $23,07 \%$, Firdaus sebesar 21,97\%, Chandra sebesar $18,68 \%, \mathrm{~d}$ a $\mathrm{n}$ Chamila sebesar $12,08 \%$.

$\mathrm{B}$ e $\mathrm{r} b$ e d a dengan Heni dan Chandra yang $\mathrm{m}$ e $\mathrm{ng}$ a 1 a $\mathrm{m} \mathrm{i}$ penurunan perilaku impulsif sebesar 19,52\%, Lusi dan

Dari tabel di atas dapat disimpulkan bahwa nilai sig pada penelitian ini adalah 0,043 sedangkan $\alpha$ bernilai 0.05 maka $\mathrm{H}_{0}$ ditolak sehingga hipotesis dalam penelitian ini diterima. Hal ini menunjukkan bahwa terapi permainan sosialisasi efektif dapat menurunkan perilaku impulsif anak ADHD di SLBN Gedangan, Sidoarjo yang ditandai dengan penurunan perilaku impulsif setelah diberikannya treatment. Penurunan perilaku impulsif bisa ditunjukkan dalam tabel berikut:

Tabel 5. Porsentase dan Rank Penurunan Perilaku Impulsif

\begin{tabular}{clccccc}
\hline No. & Nama & Pretest & Posttest & Selisih & Porsentase (\%) & Rank \\
\hline 1. & Heni & 80 & 58 & 22 & 24,17 & I \\
2. & Chandra & 75 & 58 & 17 & 18,68 & IV \\
3. & Firdaus & 79 & 59 & 20 & 21,97 & III \\
4. & Chamila & 72 & 61 & 11 & 12,08 & V \\
5. & Lusi & 82 & 61 & 21 & 23,07 & II \\
\hline & Jumlah & 388 & 297 & 91 & 100 & \\
\hline
\end{tabular}

Chamila mengalami penurunan sebesar 20,53\%. Sedangkan Firdaus mengalami penurunan perilaku impulsif sebesar 19,86\%. Disini yang tampak berpengaruh terhadap pemberian terapi permainan sosialisasi adalah Lusi dan Chamila meskipun pada saat pre-test Lusi adalah subjek yang paling impulsif dibandingkan dengan Chamila yang rendah perilaku impulsifnya. Dalam post-test ketiga dan keempat perubahan yang signifikan terjadi ditandai $\mathrm{d}$ e $\mathrm{n}$ g a $\mathrm{n}$ menurunnya perilaku impulsif $\mathrm{p}$ a d a a n a k ADHD.

\section{PEMBAHASAN}

Pada pre-test I, II, III, dan IV setiap subjek mengalami kenaikan dan kestabilan perilaku yaitu pada pre-test II, III, hingga IV yang sudah dipaparkan dalam penjelasan masingmasing skor pre-test di atas. Hasil pada posttest juga sudah didapatkan oleh peneliti, yaitu terjadi penurunan perilaku impulsif yang signifikan pada anak ADHD. Subjek yang mengalami penurunan signifikan yang
Penanganan atau treatment itu seperti mengajarkan bagaimana anak diminta untuk menjelaskan apa yang baru saja dilakukan dan mengapa anak melakukannya tanpa berpikir, mengurangi kadar situasi saat emosi anak kuat, mengajari menunda kepuasan, dan mengajari proses pemecahan masalah. Keempat hal tersebut terdapat pada terapi 
permainan sosialisasi dan menjadi konsep dasar atau tujuan dari permainan-permainan yang diterapkan dalam terapi tersebut, yaitu yang pertama adalah permainan meluncur di peluncuran. Salah satu tujuannya adalah mengajarkan subjek melaksanakan proses menaiki anak tangga dengan mematuhi peraturan dalam permainan ini, yaitu tertib bergiliran dalam menaiki anak tangga. Disini subjek akan diajarkan untuk menunda kepuasan dengan sabar dalam menunggu sampai gilirannya meluncur. Permainan kedua adalah bermain ayunan. Salah satu tujuannya adalah melatih kemampuan kontrol diri dan bertanggung jawab akan keselamatan dirinya dan teman sepermainannya. Ini bisa juga diartikan bahwa permainan dapat mengurangi kadar situasi saat emosi subjek meningkat untuk segera bergantian bermain ayunan, juga saat emosi kesenangan yang meninggi ketika berayun maupun mengayunkan ayunan temannya.

Permainan ketiga adalah bermain puzzle. Salah satu tujuannya adalah mengajarkan proses untuk memecahkan masalah. Dalam permainan puzzle subjek akan memasang dan melepas kepingan berupa potongan-potongan gambar, sehingga subjek tanpa sadar telah dilatih untuk berpikir kreatif dan subjek akan secara aktif mengembangkan kemampuannya membuat kesimpulan (dari sebuah masalah), memahami logika sebabakibat dan gagasan bahwa objek yang utuh sebenarnya tersusun dari bagian-bagian yang kecil.

Permainan keempat adalah melempar bola. Dalam permainan ini subjek secara bergantian akan memiliki kesempatan menerima dan melempar bola sebagai bentuk dari terjalinnya sebuah interaksi antar-subjek. Salah satu tujuannya adalah subjek diajarkan untuk menunda kepuasan dengan bersabar menunggu giliran untuk melempar dan menangkap bola. Permainan yang terakhir adalah estafet bola. Disini subjek akan diajarkan bekerja sama dengan temantemannya agar subjek bisa belajar berhati-hati dalam membawa bola agar bisa sampai ke subjek lainnya. Ini berarti bahwa subjek memiliki peluang yang kecil untuk bertindak tanpa dipikirkan dahulu seperti memaksakan kehendak pada orang lain, mengganggu orang lain, atau usil di dalam kelas atau saat bermain.

Proses terapeutik yang terdapat pada setiap permainan dalam terapi permainan sosialisasi ini merupakan salah satu cara yang efektif untuk menurunkan atau mengurangi perilaku impulsif pada subjek. Hal itu dikarenakan dalam permainan tersebut subjek diajarkan untuk sabar menunggu giliran melalui tahapan-tahapan dan langkahlangkah saat terapi permainan sosialisasi ini diterapkan kepada subjek.

Secara umum perilaku impulsif menurun sejak pemberian treatment kedua dan mengalami penurunan yang stabil hingga pada treatment ke-16. Treatment pada hari pertama subjek diberikan permainan meluncur di peluncuran pada 20 menit pertama, ayunan pada 20 menit berikutnya, bermain puzzle pada 20 menit selanjutnya, dan disusul permainan melempar bola pada 20 menit keempat hingga permainan estafet bola pada 20 menit terakhir. Salah satu kelebihan dari terapi permainan sosialisasi adalah subjek dalam penelitian ini tidak sadar sepenuhnya bahwa sedang diterapi. Hal itu dikarenakan permainan-permainan yang diterapkan kepada mereka bersifat hiburan atau permainan yang pernah dilakukan. Pemainan-permainan itu sendiri diberikan secara rutin sebanyak enam kali dalam satu minggu hingga hari ke-16 pemberian treatment dan subjek dinyatakan mengalami penurunan perilaku impulsifnya.

Penelitian tersebut menunjukkan bahwa terapi permainan sosialisasi terbukti berhasil diterapkan pada subjek. Hal ini 
didasarkan pada hasil pemberian pre-test dan post-test yang memiliki perbedaan. Hasil tersebut memberikan kesimpulan bahwa terjadi penurunan perilaku impulsif setelah diberikan terapi permainan sosialisasi hingga menunjukkan penurunan perilaku impulsif yang stabil pada saat diberikan post-test.

Treatment ini memberikan efek perubahan perilaku impulsif pada subjek yang awalnya suka mengintroduksi orang lain, sulit menunggu giliran pada saat bermain atau dalam situasi kelompok, memaksakan kehendak pada orang lain, kesulitan mengikuti aturan dan perintah, mengganggu orang lain atau usil di dalam kelas atau saat bermain, dan ada penurunan tingkat reaktivitas sehingga subjek tidak dijauhi oleh orang sekitarnya dan bisa memiliki teman seiring dengan perubahan perilaku. Hubungan sebab-akibat itu dapat dikembalikan pada perilaku impulsif yang dimiliki anak ADHD itu sendiri yang bisa menyebabkan dijauhi orang lain karena interaksi yang buruk, begitu juga sebaliknya. Menurut Jeffree (2009), perilaku impulsif anak ADHD dapat menurun atau berkurang karena adanya suatu treatment yang berhasil diberikan pada subjek tersebut. Statement Jefree itu didukung pula oleh Pavlov yang mengatakan bahwa dengan adanya stimulus maka respon yang diharapkan akan muncul melalui adanya sebuah pembiasaan. Hal itu sekiranya sesuai dengan penelitian yang menggunakan terapi permainan sosialisasi ini sehingga pembiasaan berupa treatment mengalami keberhasilan dalam pelaksanaannya.

Hasil penelitian ini mendukung hasil penelitian yang relevan yang dilakukan oleh Chusairi (2006) tentang penerapan terapi permainan sosialisasi yang dilakukan pada anak autis. Ini menandakan bahwa terapi tersebut efektif untuk menangani perilaku impulsif anak dengan ADHD. Perilaku impulsif anak ADHD sendiri memiliki tiga aspek, yaitu keengganan menunda respon (ketidaksabaran), bertindak tanpa dipikirkan dahulu, dan reaktif. Keengganan menunda respon ditunjukkan dengan perilaku seperti mengintroduksi orang lain dan sulit menunggu giliran pada saat bermain atau dalam situasi kelompok. Bertindak tanpa dipikirkan dahulu ditunjukkan dengan perilaku seperti memaksakan kehendak pada orang lain, kesulitan mengikuti aturan, dan mengganggu orang lain atau usil. Reaktif ditunjukkan dengan perilaku sulit dikendalikan pada saat berada di kelas dan saat bermain. Perilaku-perilaku tersebut berdampak negatif bagi anak tersebut dan bagi orang lain sehingga dibutuhkan suatu penanganan yang efektif untuk membantu mengatasi permasalahan tersebut (Dolphio, 2009).

Menurut Jeffree (2009), perilaku impulsif yang dimiliki anak dengan ADHD (seperti bertindak semaunya sendiri tanpa dipikirkan terlebih dahulu, keengganan menunda respon, dan sikap reaktif yang bisa merugikan dirinya sendiri dan orang lain) membuat mereka akan dijauhi oleh orang lain karena hubungan sosialisasinya yang buruk. Oleh karena itu, diperlukan adanya suatu upaya untuk meminimalisir hal tersebut agar tidak menetap atau berkelanjutan, salah satunya adalah melalui penerapan terapi permainan sosialisasi yang diharapkan adanya penurunan perilaku impulsif pada anak dengan ADHD.

Maksud dari terapi permainan sosialisasi ini adalah untuk memberikan intervensi kepada subjek penelitian agar dapat meningkatkan perilaku positif sesuai harapan. Karena terapi permainan semacam ini sangat dekat dengan keseharian anak dengan ADHD, maka semakin mudah untuk membantu mengubah perilaku anak menjadi lebih baik dari sebelumnya. Teori dari Jeffree ini didukung oleh Erikson bahwa perkembangan sosial seorang anak ditandai dengan kemampuan berinteraksi dengan 
lingkungannya. Dimana bermain dengan orang lain akan membantu anak untuk mengembangkan hubungan sosial dan belajar memecahkan masalah. Menurut Erikson, pada usia 5-11 tahun anak diharapkan lebih banyak terlibat dalam kegiatan games with rules, dimana kegiatan anak lebih banyak dikendalikan oleh peraturan permainan sehingga seorang anak dapat diajarkan untuk mematuhi aturan yang ada di sekitarnya (dalam Santrock, 1995).

Pengembangan sosial, emosional, dan kemandirian, dimaksudkan untuk membina anak agar dapat mengendalikan emosinya secara wajar dan dapat berinteraksi dengan baik dengan sesamanya maupun dengan orang dewasa serta dapat menolong dirinya sendiri dalam rangka kecakapan hidup. Permainan juga memungkinkan anak melepaskan energi fisik yang berlebih dan membebaskan perasaan-perasaan yang terpendam sehingga terapi permainan sosialisasi dapat membantu subjek mengurangi perilaku impulsif yang mereka miliki.

Ditinjau dari sekolah tempat mereka mendapatkan pendidikan, bisa dikatakan anak-anak di SLBN Gedangan, Sidoarjo mendapatkan perhatian khusus dan intensif sehingga tidak ada yang tidak mungkin bagi anak tersebut untuk menjadi lebih baik dari sebelumnya meskipun tidak bisa disembuhkan secara total.

Faktor lain yang dapat membantu menurunkan perilaku impulsif anak di luar sekolah adalah faktor pengasuhan atau pola asuh orang tua yang bisa menempatkan diri sebagai orang tua yang baik untuk anaknya. Orang tua harus memberikan perhatian dan bukan malah mengacuhkan anak mereka yang mengalami gangguan. Tidak sedikit orang tua yang mengacuhkan anak mereka dan sepenuhnya menyerahkan penanganan kepada pihak sekolah. Setelah anak mereka pulang kegiatan yang dilakukan di rumah hanya berdiam diri, bermain, dan tidur. Mereka tidak mendapatkan apa yang seharusnya mereka dapatkan seperti di sekolah.

\section{SIMPULAN}

Berdasarkan hasil penelitian ini dapat ditarik kesimpulan bahwa terapi permainan sosialisasi efektif diberikan pada anak dengan ADHD untuk menurunkan perilaku impulsif mereka. Semakin sering terapi ini diberikan maka semakin rendah perilaku impulsif yang dimiliki anak-anak ADHD ini. Tingkat penurunan perilaku impulsif juga bisa dikatakan signifikan. Secara teoritis, hasil penelitian ini akan berguna untuk menambah pengetahuan yang sudah ada tentang cara penanganan anak dengan ADHD terutama dalam konteks pendidikan anak berkebutuhan khusus di sekolah. Secara praktis, hasil penelitian ini akan memberi informasi pada para guru dan terapis ABK dalam menghadapi anak berkebutuhan khusus (ABK), khususnya anak ADHD yang memiliki kesulitan dalam hal akademik dan interaksi sosialnya.

\section{SARAN}

Berdasarkan kesimpulan dari penelitian yang telah dilakukan, maka penulis dapat merumuskan dan mengajukan beberapa saran yang berkaitan dengan penelitian ini. Untuk guru, dalam memberikan terapi permainan sosialisasi bagi anak ADHD hendaknya dalam satu minggu dilakukan terapi minimal tiga kali atau sesering mungkin agar anak-anak yang memiliki perilaku impulsif dapat dikurangi karena melihat efektivitas dari terapi ini. Untuk orang tua, perlu adanya kerja sama antara orang tua dan guru dalam kegiatan terapi permainan sosialisasi ini guna menunjang keberhasilan dari terapi ini. Terapi ini tidak hanya dilakukan di sekolah, tetapi bisa juga 
diberikan di rumah dan dapat dikombinasikan dengan permainan lain. Untuk peneliti selanjutnya, diharapkan hasil penelitian ini bisa dijadikan salah satu sumber referensi untuk melakukan penelitian selanjutnya yang berhubungan dengan perilaku-perilaku yang muncul pada anak dengan ADHD.

\section{DAFTAR PUSTAKA}

Arikunto, S. (2009). Manajemen Penelitian. Jakarta: Rineka Cipta.

Veskarisyanti, G. A. (2008). 12 Terapi Autis. Yogyakarta: Pustaka Anggrek.

Barkley, R. A. (1997). Behavioral inhibition, sustained attention, \& executive functions: constructing a unifying theory of ADHD. Psychological Bulletin, 121:1, 65-94.

Chusairi, Ahmad. (2006). Efektivitas Terapi Bermain Sosial Untuk Meningkatkan Kemampuan dan Keterampilan Sosial Anak Dengan Gangguan Autis. Surabaya: UNAIR.

Djarwanto. (2009). Statistik Non Parametrik. Yogyakarta: BPFE.
Dolphio, Bandi. (2009). Layanan Perilaku Anak Hiperaktif. Sleman: PT Intan Sejati Klaten.

Nevid, S., dkk. (2005). Psikologi Abnormal. Erlangga.

Puspandita, Rianti. (2010). Psikologi Anak Khusus. Http://riantipuspaandita. wordpress.com/category/psikologi-anakkhusus/page/6/. Diakses pada 16 Juni 2011.

Santrock, W. (1995). Life-Span Development. Erlangga.

Somantri, Sutjihati. (2006). Psikologi Luar Biasa. PT. Refika Aditama. 